\title{
TWO NEW SPECIES OF THE GENUS PTYCHOLAIMELLUS COBB, 1920 (NEMATODA: CHROMADORIDAE) FROM COASTAL ZONE OF NORTH VIETNAM SEA
}

\author{
Nguyen Vu Thanh ${ }^{1 *}$, Nguyen Dinh $T u^{1}$, Vladimir G. Gagarin ${ }^{2}$, \\ Alekcei V. Tchesunov ${ }^{3}$, Nguyen Thanh Hien ${ }^{1}$ \\ ${ }^{1}$ Institute of Ecology and Biological Resources, VAST, *nvthanh49@yahoo.com \\ ${ }^{2}$ Institute of Inland Water Biology, Russian Academy of Science \\ ${ }^{3}$ Moscow State University, Faculty of Biology, Department of Invertebrate Zoology
}

\begin{abstract}
Two new marine nematode species of the family Chromadoridae collected from coastal zone of North Vietnam sea were described and illustrated are Ptycholaimellus brevisetosus $\mathrm{sp} . \mathrm{n}$. and Ptycholaimellus areniculus sp. $\mathrm{n}$.. The new species $P$. brevisetosus $\mathrm{sp}$. $\mathrm{n}$. resembles to $P$. pandispiculatus (Hopper, 1961) but differs from it by the longer body, absence of somatic and cervical setae, more wide labial region, longer cephalic setae and longer spicules, and $P$. areniculus sp. n. resembles to $P$. macrodentatus (Timm, 1961) but differs from it by the longer body, relatively shorter cephalic setae, absence of knob-like swellings at base of dorsal tooth in stoma and presence of small piece in spicular apparatus of males.
\end{abstract}

Keywords: Chromadoridae, Ptycholaimellus, free-living marine nematodes, new species, North Vietnam coastal sea.

\section{INTRODUCTION}

The fauna of marine nematodes has been studied recently in Vietnam. At present, this investigating field on nematode biodiversity is strongly improved in connection with building up basic biomonitoring data for water quality assessment in watershed and wetland ecosystems along the country's coatline. This work is revealed as a part of the project funded by Vietnam Academy of Science and Technology (VAST) for study of biodiversity and free-living nematode fauna of the coast of Vietnam. The nematode samples were collected in March 2010 and November 2012. In this paper two new species of the genus Ptycholaimellus Cobb, 1920 (Chromadoridae), Ptycholaimellus brevisetosus sp. n. and Ptycholaimellus areniculus sp. n., were described and illustrated.

\section{MATERIALS AND METHODS}

Sample collecting: samples were scraped by Ponnar grab. Then top $10 \mathrm{~cm}$ sediment was collected by a plastic tube corer $\left(10 \mathrm{~cm}^{2}\right)$ with three replicates from each site and fixed with $10 \%$ hot formalin solution. Additionally, samples for granulometric analysis were also taken with a plastic tube.

Sample processing: after washing samples onto a $40 \mathrm{~m}$, nematodes were extracted with Ludox TM-50 $(\mathrm{d}=1.18)$. The extraction was repeated three times (Heip et al., 1985). Maximum of 200 nematodes were randomly picked, transferred in anhydrous glycerol and mounted on slides for identification and counting.

Abbreviations used in the text: $\mathrm{L}=$ total body length $(\mu \mathrm{m}) ; \mathrm{a}=$ body length divided by maximum body width; $b=$ body length divided by pharyngeal length; $\mathrm{c}=$ body length divided by tail length; $\mathrm{c}^{\prime}=$ tail length divided by cloacal or anal body diameter; V (\%) = relation of distance from anterior body end to vulva for body length in percentage.

\section{DESCRIPTION}

Order Chromadorida Chitwood, 1933

Family Chromadoridae Filipjev, 1929

Genus Ptycholaimellus Cobb, 1920

1. Ptycholaimellus brevisetosus sp. n. (Fig.1, Table 1)

Male: body slender, medium size. Cuticle annulated, thin. Thickness cuticle at middle of 
body about $1.0 \mu \mathrm{m}$. Lateral fields $6-7 \mu \mathrm{m}$ wide, begin at level of stoma and extend to tail middle. In the beginning lateral fields have no transverse crosspieces which appear at level of the middle of oesophagus length. Somatic setae absent. Lips well developed, isolated from other body. Inner labial sensillae and outer labial sensillae badly visible, in shape of small papillae. Cephalic sensillae in shape of thin setae and being 55-60\% of labial region width. Cheilostoma armed by 12 ribs. In esophastoma one big dorsal tooth, apical end which hook-like bend and two small subventral denticles. Knob-like swellings at base of dorsal tooth absent. Walls of anterior portion of esophastoma strongly cuticularized and at its outer dorsal side have rather long apophysis. Amphidial fovea in shape of transverse split and situated at lips bases.

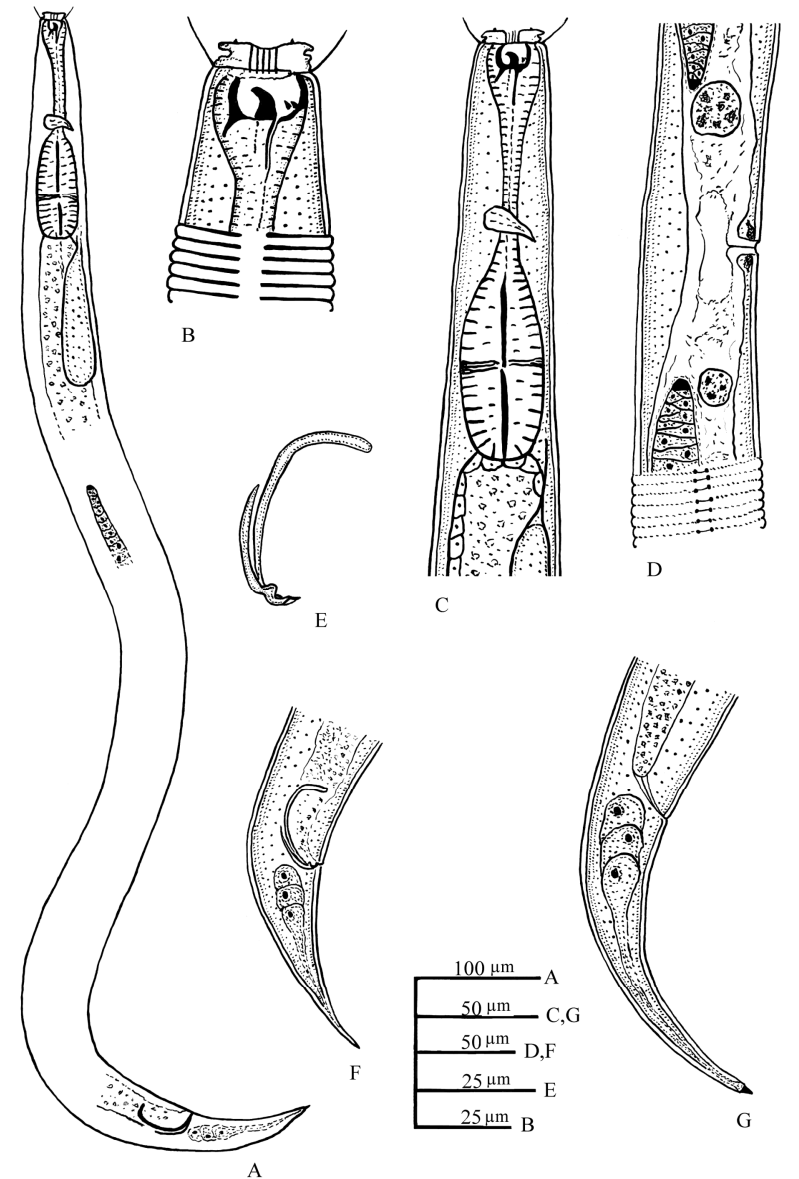

Figure 1. Ptycholaimellus brevisetosus sp. $\mathrm{n}$.

A. Entire male; B. Head region; C. Anterior end of body; D. Vulva region;

E. Spicular aparatus; F. Male tail; G. Female tail.

Oesophagus muscular with big basal bulb, divided at two portions. Basal bulb being 39$45 \%$ of oesophagus length. Cardia not visible. Renette baggy-shaped, large. Its length being $50-65 \%$ of oesophagus length. Testis one, anterior, situated to left side of intestine. Spicules paired, strongly bent ventrally, 1.4-1.6 times as long as cloacal body diameter.
Gubernaculums paired, only slightly bent . At apical end of each gubernaculums are two small lateral apophysis, covered spicules and also small hook-like apophysis. Supplements absent. Tail elongate-conical, gradually narrowing. Caudal setae absent. Caudal glands and spinneret well developed. Spinneret finger-like, 10-12 $\mu \mathrm{m}$ long. Females: general appearance 
similar to that of male. Structure of cuticle and anterior portion of body similar to males. Gonads didelphic, amphidelphic; ovaries antidromous, with long bends. Anterior ovary situated to right side of intestine, posterior ovary situated to left side of intestine. Vulva of transverse slit, equatorial, its lips not cuticularized and not protruding outside the body counter. Vulvar glands comparatively small. Both uterus spacious. Spermathecas oval, 20-31 $\mu \mathrm{m}$ diameter. Tail elongate-conical, gradually narrowing. Caudal glands and spinneret well developed.

Table 1. Measurements of Ptycholaimellus brevisetosus sp. $\mathrm{n}$. (all measurements in $\mu \mathrm{m}$, except ratio)

\begin{tabular}{|c|c|c|c|c|c|}
\hline \multirow{3}{*}{ Characteristics } & \multirow{3}{*}{$\underset{\substack{\pi \\
\text { Holotype }}}{ }$} & \multicolumn{4}{|c|}{ Paratypes } \\
\hline & & \multicolumn{2}{|c|}{$4 \hat{\jmath}$} & \multicolumn{2}{|c|}{6 우우 } \\
\hline & & range & mean & range & mean \\
\hline $\mathrm{L}$ & 1103 & $1049-1202$ & 1113 & $1205-1518$ & 1323 \\
\hline $\mathrm{a}$ & 18 & $17-26$ & 21 & $18-26$ & 22 \\
\hline $\mathrm{b}$ & 6.0 & $5.4-6.2$ & 5.8 & $5.7-6.6$ & 6.2 \\
\hline $\mathrm{c}$ & 10.2 & $10.0-11.2$ & 10.6 & $8.9-12.7$ & 10.5 \\
\hline c' & 2.8 & $2.7-4.2$ & 3.2 & $3.5-5.1$ & 4.3 \\
\hline $\mathrm{V} \%$ & - & - & - & $45.7-52.5$ & 49.2 \\
\hline Labial region width & 26 & $26-28$ & 27 & $27-29$ & 28 \\
\hline Cephalic setae length & 15 & $15-16$ & 15 & $15-16$ & 15 \\
\hline Oesophagus length & 185 & $176-221$ & 195 & $187-252$ & 212 \\
\hline Oesophageal bulb length & 83 & $72-90$ & 83 & $86-112$ & 94 \\
\hline Posterior end of oesophagus to vulva & - & - & - & $353-536$ & 439 \\
\hline Posterior end of oesophagus to cloaca & 810 & $738-873$ & 811 & - & - \\
\hline Renette length & 92 & $90-113$ & 104 & $89-117$ & 105 \\
\hline Vulva to anus & - & - & - & $500-630$ & 542 \\
\hline Tail length & 108 & $98-115$ & 107 & $95-180$ & 130 \\
\hline Spicule length & 53 & $52-56$ & 53 & - & - \\
\hline Gubernaculum length & 32 & $32-34$ & 33 & - & - \\
\hline
\end{tabular}

Type locality and habitat: littoral of North Vietnam sea, latitude $21^{\circ} 13.476$, longitude 10722.467'. Depth of waters $1.5-2.0 \mathrm{~m}$, sand, salinity $24 \%$.

Type material: holotype male, slide number 100/29 and one female paratypes, deposited at the Nematode Collection, Center of Parasitology, Institute of Ecology and Evolution, RAS, Moscow, Russia. Paratypes: 4 males and 5 females deposited at the Nematode Collection, Institute of Ecology and Biological Resources, VAST, Hanoi, Vietnam.

Differential diagnosis: the new species resembles to Ptycholaimellus pandispiculatus (Hopper, 1961) Wieser \& Hopper, 1967, which was found at coastal of Mexico (Hopper, 1961) by structure of spicular apparatus, but differs from it by the longer body (in $P$. pandispiculatus $\mathrm{L}=970-1140 \mu \mathrm{m} v$ s. $\mathrm{L}=1049$ 1598 in new species), absence of somatic and cervical setae, more wide labial region (in $P$. pandispiculatus labial region $15 \mu \mathrm{m}$ wide $v$ s. 26-32 $\mu \mathrm{m}$ in new species, longer cephalic setae (in $P$. pandispiculatus cephalic setae 6-7 $\mu \mathrm{m}$ long vs. $15-16 \mu \mathrm{m}$ in new species) and longer spicules (in P. pandispiculatus spicules $40 \mu \mathrm{m}$ long $v$ s. 52-56 $\mu \mathrm{m}$ in new species).

Etymology: the species name means "long setae", "with long setae".

2. Ptycholaimellus areniculus sp. n. (Fig. 2, Table 2)

Male: body slender, medium size. Cuticle annulated, thin. Thickness cuticle at middle of body $0.7-1.0 \mu \mathrm{m}$. Lateral fields $4-5 \mu \mathrm{m}$ wide, 
begin at level of stoma and extend to tail middle. In the beginning lateral fields have no transverse crosspieces which appear at level of the middle of oesophagus length. Somatic setae absent. Lips well developed, isolated from other body. Inner labial sensillae and outer labial sensillae badly visible, in shape of small papillae. Cephalic sensillae in shape of thin setae and being $30-33 \%$ of labial region width. Cheilostoma armed by 12 ribs. In esophastoma one big dorsal tooth, apical end which hook-like bend, and two small subventral denticles. Knoblike swellings at base of dorsal tooth absent. Walls of anterior portion of esophastoma strongly cuticularized and at its outer dorsal side have long apophysis. Amphidial fovea in shape of transverse split and situated at lip bases. Oesophagus muscular with big basal bulb, divided at two portions. Basal bulb being 36$44 \%$ of total oesophagus length. Cardia not visible. Renette baggy-shaped, large. Its length being $53-65 \%$ of oesophagus length.

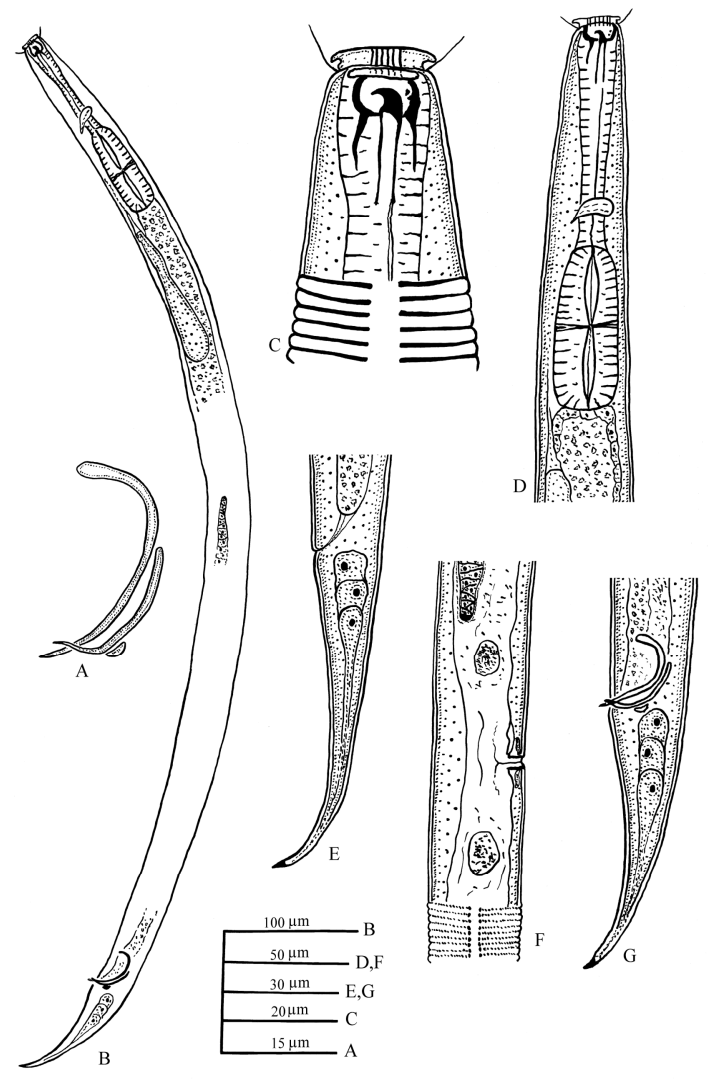

Figure 2. Ptycholaimellus areniculus sp. n.

A. Spicular apparatus; B. Entire male; C. Head region; D. Anterior end of body;

E. Female tail; F. Vulva region; G. Male tail.

Testis one, anterior, situated to left side of intestine. Spicules paired, strongly bent ventrally, 1.5-1.7 times as long as cloacal body diameter. Gubernaculums paired, only slightly bent. There is also small, oval, sclerotized piece. Precloacal supplements absent. Tail elongateconical, gradually narrowing. Caudal glands and spinneret well developed. Spinneret finger-like,

\section{5-6 $\mu \mathrm{m}$ long.}

Female: general appearance similar to that of males. Structure of cuticle and anterior portion of body similar to males. Gonads didelphic, amphidelphic; ovaries antidromous with long bends. Anterior ovary situated to right side of intestine, posterior ovary situated to left side of intestine. Vulva a transverse slit, 
equatorial, its lips not cuticularized and not protruding outside the body counter. Vulvar glands comparatively small. Both uterus spacious. Spermathecas oval, 15-21 $\mu \mathrm{m}$ diameter. Tail elongate-conical, gradually narrowing. Caudal glands and spinneret well developed.

Type locality and habitat: littoral of North Vietnam sea, latitude $21^{\circ} 13.476$, longitude $107^{\circ} 22.467^{\prime}$. Depth of waters $1-2 \mathrm{~m}$, sediment of sand, salinity $24 \%$.

Type material: holotype male on slide number 100/31 deposited at the Nematode Collection, Center of Parasitology, Institute of Ecology and Evolution, RAS, Moscow. Paratypes 9 ठิ $\hat{O}$ and 9 우 deposited at the
Nematode Collection, Institute of Ecology and Biological Resources, VAST, Hanoi, Vietnam.

Differential diagnosis: the new species resembles to Ptycholaimellus macrodentatus (Timm, 1961) Wieser \& Hopper, 1967, but differs from it by the longer body (in $P$. macrodentatus ठิ ${ }^{\top} \mathrm{L}=621-670 \mu \mathrm{m}$, 우 796$823 \mu \mathrm{m} v s$. ठึ $\mathrm{L}=715-882$ 우우 $\mu \mathrm{m}$, 오오 $\mathrm{L}=$ $863-1069 \mu \mathrm{m}$ in new species), relatively shorter of cephalic setae (in P. macrodentatus cephalic setae are equal to width of labial region vs. length of cephalic setae being 30-33\% of labial region width in new species), absence of knoblike swellings at base of dorsal tooth and presence of small oval piece in spicular apparatus of males (Timm, 1961).

Table 2. Measurements of Ptycholaimellus areniculus sp.n. (all measurements in $\mu \mathrm{m}$, except ratio)

\begin{tabular}{|c|c|c|c|c|c|}
\hline \multirow{3}{*}{ Characteristics } & \multirow{3}{*}{ Holotype } & \multicolumn{4}{|c|}{ Paratypes } \\
\hline & & \multicolumn{2}{|c|}{$90^{\pi} 0^{\pi}$} & \multicolumn{2}{|c|}{$9 q 9$} \\
\hline & & range & mean & range & mean \\
\hline $\mathrm{L}$ & 740 & $715-882$ & 806 & $863-1069$ & 958 \\
\hline $\mathrm{a}$ & 23 & $20-24$ & 22 & $18-27$ & 24 \\
\hline $\mathrm{b}$ & 5.5 & $4.9-5.8$ & 5.4 & $5.2-6.5$ & 5.7 \\
\hline $\mathrm{c}$ & 10.2 & $9.4-13.2$ & 10.6 & $8.8-11.9$ & 10.1 \\
\hline c' & 3.2 & $3.0-3.7$ & 3.4 & $3.6-5.4$ & 4.7 \\
\hline V\% & - & - & - & $46.2-50.1$ & 48.6 \\
\hline Labial region width & 16 & $15-18$ & 17 & 16-19 & 18 \\
\hline Cephalic setae length & 6.0 & $6.0-7.0$ & 6.5 & $6.0-7.5$ & 6.5 \\
\hline Oesophagus length & 155 & $135-162$ & 149 & $158-176$ & 168 \\
\hline Oesophageal bulb length & 47 & $47-68$ & 62 & $60-81$ & 73 \\
\hline Posterior end of oesophagus to vulva & - & - & - & $248-338$ & 297 \\
\hline Posterior end of oesophagus to cloaca & 533 & $533-648$ & 581 & - & - \\
\hline Renette length & 92 & $75-120$ & 89 & $79-113$ & 98 \\
\hline Vulva to anus & - & - & - & $340-461$ & 397 \\
\hline Tail length & 72 & $72-88$ & 76 & $86-113$ & 96 \\
\hline Spicule length & 36 & $36-39$ & 38 & - & - \\
\hline Gubernaculum length & 23 & $20-23$ & 22 & - & - \\
\hline
\end{tabular}

Remarks: Ptycholaimellus macrodentatus (Timm, 1961) was found and described from Kenyan coast of Indian Ocean by Muthumbi and Vincx (1998). However, vermes of this nematode population differs from vermes of types nematode population from Bengal Bay by the longer body $(621-670 \mu \mathrm{m}$ in $P$. macrodentatus), relatively shorter of cephalic setae ( $8 \mathrm{~m}$ in $P$. macrodentatus), absence of knob-like swellings at the base of dorsal tooth and presence of small, oval piece in spicular apparatus of male. With these differentation we proposed the Kenyan population of "P. macrodentatus" is belong to new species: Ptycholaimellus areniculus sp. $\mathrm{n}$.

Etymology: the species name means 
"sandy", "from sand".

Acknowledgements: This work was supported by Vietnam Academy Science and Technology Tecnology Foundation under grants VAST.ĐL.12/11-12; VAST.HTQT.NGA 01/2012-2013 and Russian grant RFBR 12-0493002-Viet.

\section{REFERENCES}

1. Dashenko, Belogurov, 1984. Morphological characteristics of the new species Ptycholaimellus adocius sp. n (Nematoda, Chromadorida) from Pocet Bay, Japanese sea. http://intramar.ugent.be/nemys/.

2. Eskin R. A., Hopper B. E., 1985. Population dynamics and description of Ptycholaimellus hibernus n. sp. (Nematode: Chromadoridae). Journal of Nematology, 17(1): 38-45.

3. Hopper B. E., 1961: Canadian Journal of
Zoology, 39: 359-365.

4. Preben Jensen and Stefen Nehring, 1992. Review of Ptycholaimellus Cobb, 1913 (Nematoda: Chromadoridae), with description of three species. Zoologia Scripta, 21(3): 239-245.

5. Muthumbi A. W., Vincx M., 1998. Hydrobiologia, 364: 119-153.

6. Timm R. H., 1961. Proceedings of the Pakistan Academy of Science, 1(1): 1-88.

7. Wieser W., Hopper B. E., 1967. Marine nematodes of the east coast of North Amrerica. I. Florida Bull. Mus. comp. Zool. Harw, 135(5): 239-344.

8. WoRMS, 2011. Ptycholaimellus Cobb, 1920. In: Deprez, T. et al., 2005.

9. NeMys. World Wide Web electronic publication. World Register of Marine Species http://www.marinespecies.org/aphia.

\title{
HAI LOÀI TUYẾN TRÙNG BIỂN MỚI THUỘC GIỐNG PTYCHOLAIMELLUS COBB, 1920 (NEMATODA: CHROMADORIDAE) Ở VÙNG BIỂN VEN BỜ MIỀN BẮC VIẸT NAM
}

\author{
Nguyễn Vũ Thanh ${ }^{1 *}$, Nguyễn Đình Tứ ${ }^{1}$, Vladimir G. Gagarin ${ }^{2}$, \\ Alekcei V. Tchesunov ${ }^{3}$, Nguyễn Thanh Hiền ${ }^{1}$ \\ ${ }^{1}$ Viện sinh thái và Tài nguyên sinh vật, Viện Khoa học và Công nghệ Việt Nam \\ ${ }^{2}$ Viện Sinh học nước nội địa Borok, Viện Hàn lâm Khoa học Liên bang Nga \\ ${ }^{3}$ Trường Đại học tổng hợp Lômonosov, Moskva. Liên bang Nga
}

\section{TÓM TẮT}

Mô tả và công bố hai loài mới tuyến trùng biển sống tự do Ptycholaimellus brevisetosus sp. n. và Ptycholaimellus areniculus $\mathrm{sp}$. $\mathrm{n}$. thuộc họ Chromadoridae ở vùng nước ven bờ các tỉnh phía Bắc Việt Nam. Về hình thái, loài tuyến trùng biển mới Ptycholaimellus brevisetosus $\mathrm{sp}$. $\mathrm{n}$. tương đối giống với loài Ptycholaimellus pandispiculatus (Hopper, 1961) nhưng có đặc điểm khác ở chỗ cơ thể dài hơn, không có các lông somatic trên cơ thể và không có lông trên vùng cổ, đường kính vùng môi rộng hơn, lông đầu dài hơn và gai sinh dục cũng dài hơn.

Loài tuyến trùng biển mới Ptycholaimellus areniculus sp. n. về hình thái tương đối giống loài Ptycholaimellus macrodentatus (Timm, 1961) nhưng có đặc điểm khác ở chỗ cơ thể dài hơn, lông đầu ngắn, trong xoang miệng ở phần gốc răng lưng không có đoạn phình lên giống kiểu dạng gốc kim hút và có sự hiện diện của miếng nhỏ dài trên bộ phận gai sinh dục.

Tù̀ khóa: Chromadoridae, Ptycholaimel, loài mới, tuyến trùng biển, Bắc Việt Nam. 